\title{
TINGKAT TRANSFER OKSIGEN KINCIR AIR SELAMA PERIODE BLIND FEEDING BUDIDAYA INTENSIF UDANG PUTIH (Litopenaeus vannamei)
}

\author{
Abdul Wafi ${ }^{\text {a }}$,Heri Ariadi ${ }^{\mathrm{b}}$, Mohammad Mahmudi ${ }^{\mathrm{c}}$, Mohamad Fadjar ${ }^{\mathrm{c}}$

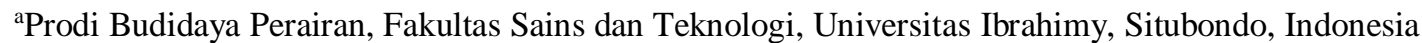

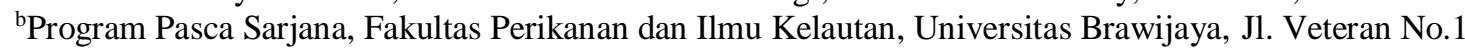 \\ Malang, Indonesia \\ 'Fakultas Perikanan dan Ilmu Kelautan, Universitas Brawijaya, Jl. Veteran No.1 Malang, Indonesia \\ *Corresponding author: ariadi_heri@yahoo.com
}

\begin{abstract}
Abstrak
Efektifitas penggunaan kincir air selama masa periode blind feeding budidaya intensif udang vannamei (Litopenaeus vannamei) merupakan salah satu kegiatan penting yang harus diperhatikan demi kelangsungan siklus budidaya yang stabil. Tujuan dari penelitian ini adalah untuk mengetahui tingkat transfer oksigen oleh kincir air serta hubunganya terhadap parameter harian kualitas air tambak. Peneltian ini dilakukan dengan konsep desain kausal ex-post facto selama 30 hari awal masa budidaya intensif udang vannamei (Litopenaeus vannamei) atau selama periode blind feeding budidaya. Hasil penelitian menunjukan bahwa nilai parameter kualitas air di lokasi tambak masih sesuai ambang batas. Sedangkan tingkat transfer oksigen oleh kincir air bersifat fluktuatif selama 30 hari masa pengamatan. Sementara dari hasil uji korelasi menunjukan bahwa hanya variabel suhu dan salinitas air memiliki keeratan hubungan yang kuat terhadap proses transfer oksigen oleh kincir. Sehingga dapat disimpulkan bahwa fluktuasi tingkat transfer oksigen oleh kincir air sangat dipengaruhi oleh kondisi suhu dan salinitas air tambak.
\end{abstract}

Kata kunci : Kincir air, Blind feeding, Litopenaeus vannamei, Budidaya intensif

\begin{abstract}
The effectivity of using of paddle wheels aerator during the blind feeding period on intensive culture of whiteleg shrimp (Litopenaeus vannamei) is an important activities that must be considered by farmers. The purpose of this study was to determine the level of oxygen transfer by paddle wheels aerator and its relationship to the daily parameters of pond water quality. This research was conducted with the ex-post facto causal design concept during the first 30 days of intensive culture of whiteleg shrimp (Litopenaeus vannamei) or during the blind feeding periods. The results of the study showed that the value of water quality parameters at the pond location was still in accordance with the threshold standart. While the level of oxygen transfer by the paddle wheels aerator fluctuated for 30 days of observation. While the results of the correlation test showed that only the temperature and salinity variables of water had a strong relationship with the oxygen transfer process by the paddle wheels aerator. It can be concluded that fluctuations in the level of oxygen transfer by paddle wheels aerator are affected by temperature and salinity.
\end{abstract}

Keywords : Paddlewheels aerator, Blind feeding, Litopenaeus vannamei, Intensive culture

\section{PENDAHULUAN}

Udang adalah primadona utama pada sektor budidaya perikanan di Indonesia dalam beberapa tahun terakhir [47]. Dengan komoditas unggulannya adalah jenis udang vannamei (L. vannamei). Udang vannamei (Litopenaeus vannamei) sendiri mulai resmi masuk ke Indonesia pada tahun 2001 silam, dan terus berkembang sampai sekarang [30]. Sistem budidaya udang vannamei di Indonesia dalam prakteknya banyak mengunakan model budidaya ekstensif, semi-intensif, dan intensif [14,42]. Dalam teknologi budidaya udang vannamei (L. vannamei) pola intensif tidak pernah lepas dari penggunaan kincir air sebagai 
sarana penting untuk aerasi dan sirkulasi air $[7,19]$.

Selain untuk memproduksi oksigen melalui proses agitasi dan homogenisasi parameter kualitas air selama periode budidaya $[17,40]$. Penggunaan kincir air pada tambak intensif juga berfungsi sebagai perekayasa arus untuk mengumpulkan lumpur dan limbah sisa pakan menuju central drain, evaporasi gas-gas beracun serta pengadukan untuk distribusi vertikal plankton pada siang hari [20,28]. Penentuan jumlah kapasitas kincir air pada tambak budidaya didasarkan pada jumlah padat tebar, kadar oksigen perairan, serta carryng capacity biomassa tambak $[8,24,40]$.

Tingkat daya dukung (carryng capacity) optimal dan kondisi kualitas air yang stabil salah satunya dipengaruhi oleh jumlah tingkat input yang diberikan saat periode blind feeding. Blind feeding sendiri adalah masa pemberian pakan buta sesuai dengan program pakan yang bersifat agregatif tanpa ada kontrol selama 25-30 hari pertama budidaya [8,34]. Berdasarkan berbagai latar belakang dan pertimbangan tersebut, maka tujuan dari penelitian ini adalah untuk mengetahui hubungan antara parameter kualitas air harian tambak intensif dengan tingkat transfer oksigen oleh kincir air selama periode blind feeding budidaya intensif udang vannamei $(L$. vannamei) berlangsung.

\section{METODE PENELITIAN}

Penelitian ini dilaksanakan dengan konsep desain kausal ex-pose facto di tambak intensif Desa Bayeman, Kecamatan Tongas, Kabupaten Probolinggo selama 30 hari pada bulan April - Mei 2019 atau pada saat masa blind feeding budidaya udang vannamei ( $L$. vannamei). Tambak operasional penelitian menggunakan tambak plastik HDPE ukuran $400 \mathrm{~m}^{2}$ dengan padat tebar 112 ekor $/ \mathrm{m}^{2}$ yang dilengkapi dengan kincir air sebanyak 4 buah dengan kapasitas masing-masing $1 \mathrm{HP}$, selama masa blind feeding kincir air hanya dinyalakan dengan kapasitas 2 HP. Sementara kegiatan pemeliharaan tambak budidaya dilakukan berdasarkan standart nasional operasional baku budidaya udang (CBIB).
Variabel yang diteliti adalah data harian kualitas air yang meliputi parameter $\mathrm{pH}$, oksigen terlarut, suhu, salinitas, dan variabel jumlah volume air tambak serta tingkat transfer oksigen oleh kincir air. Pengambilan sampel kualitas air dilakukan pada kedalaman $90 \mathrm{~cm}$ dari permukaan air tambak, serta dilaksanakan pada jam 06.00, 12.00, dan 21.00 atau didasarkan pada trend fluktuasi waktu hasil pengukuran dinamika harian oksigen terlarut di tambak yang dilakukan pengukuran setiap 1 jam sekali selama 24 jam non-stop pada saat budidaya umur 1 hari pasca tebar (Gambar 1.). Sedangkan variabel data tingkat transfer oksigen diambil pada pukul 21.00 untuk menghindari adanya bias sumbangan produksi oksigen dari proses fotosintesis. Keseluruhan variabel penelitian dilakukan pengambilan data secara berkala setiap 2 hari sekali selama 30 hari masa blind feeding budidaya udang.

Kadar konsentrasi oksigen terlarut dan suhu air tambak diukur menggunakan AZ Instrument Dissolved Oxygen Meter (Type AZ 8402), konsentrasi pH tambak diukur menggunakan HANNA $\mathrm{pH}$ tester (type HI98107), sedangkan kadar salinitas tambak ditentukan berkala dengan menggunakan alat hand-refraktometer MASTER-S10 ATAGO. Sementara kapasitas volume air tambak ditentukan dengan melihat nilai tinggi air pada water stick level. Untuk tingkat transfer oksigen oleh kincir air diestimasi berdasarkan rumus persamaan dibawah ini [4] :

$$
\begin{aligned}
& \text { OTR }=\text { SOTR } \times \frac{(\text { Cs }- \text { Cp })}{9.09} \times 1,024^{\mathrm{T}-20} \times \alpha \\
& \text { SOTR }=\left(\mathrm{K}_{\mathrm{L}} \alpha\right) \times(\text { Csat }) \times(\mathrm{V}) \times\left(10^{-3}\right)
\end{aligned}
$$

Dimana $O T R$ dalah tingkat transfer oksigen $\left(\mathrm{mgO}_{2} / \mathrm{L} / \mathrm{jam}\right), 1,024^{T-20}$ adalah faktor koreksi temperatur tambak, SOTR ialah tandar tingkat transfer oksigen $\left(\mathrm{mgO}_{2} / \mathrm{L} / \mathrm{jam}\right), \quad C_{s}$ nilai salinitas tambak, $C_{p}$ konsentrasi oksigen jenuh tambak, $C_{\text {sat }}$ nilai persen saturasi kolam, $K_{L} \alpha$ koefisien transfer gas $\left(\mathrm{mgO}_{2} / \mathrm{L} / \mathrm{jam}\right), \quad \alpha$ koefisien keseimbangan $\left(\mathrm{mgO}_{2} / \mathrm{L} / \mathrm{jam}\right), \quad v$ volume air tambak $\left(\mathrm{m}^{3}\right)$, dan 9.09 adalah nilai deviasi oksigen transfer.

Untuk mengetahui hubungan keterkaitan antara masing-masing variabel penelitian, maka dilakukan analisis korelasi dengan bantuan software SPSS ver. 16. 


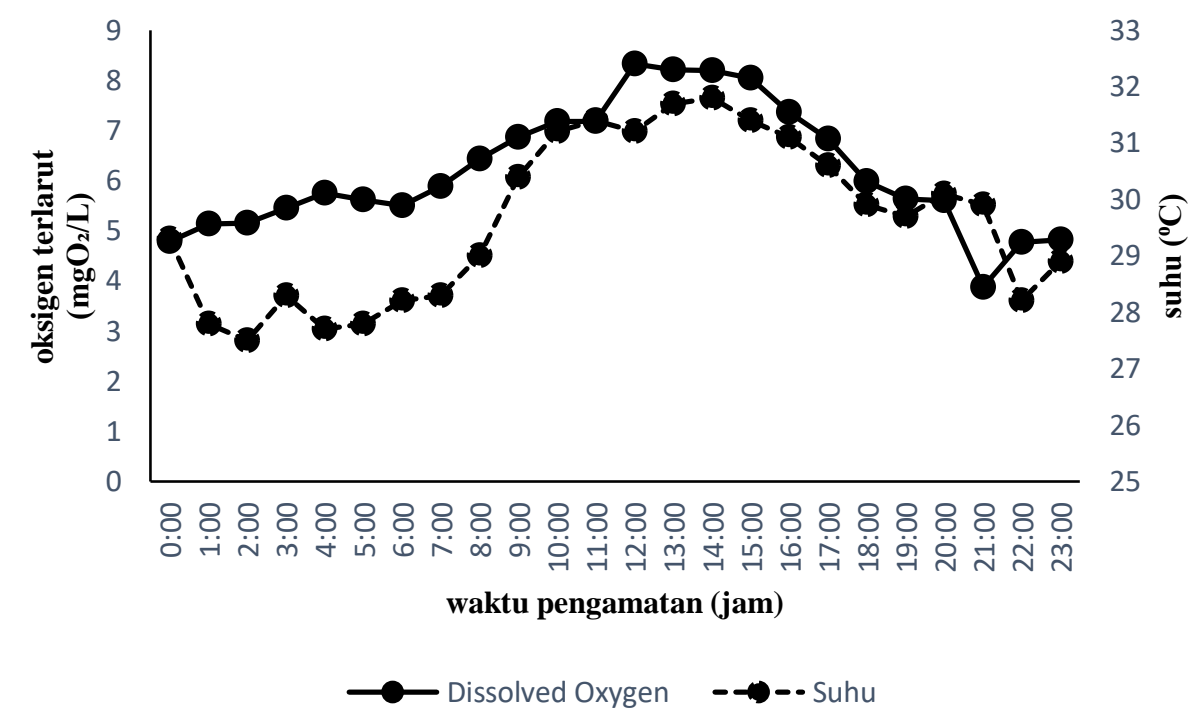

Gambar 1. Dinamika kelarutan oksigen dan suhu di tambak selama 24 jam.

\section{HASIL DAN PEMBAHASAN}

\section{Dinamika tingkat transfer oksigen kincir air selama periode blind feeding}

Dinamika tingkat transfer oksigen oleh kincir air per $1 \mathrm{HP}$ selama masa penelitian dapat dilihat pada Gambar 2. Dari hasil penelitian selama periode blind feeding menunjukan bahwa tingkat transfer oksigen oleh aktifitas penggunaan kincir air bersifat fluktuatif. Tingkat transfer oksigen tertinggi terdeteksi pada umur budidaya 5 hari sebesar $1.21 \mathrm{mgO}_{2} / \mathrm{L} / \mathrm{jam}$, sedangkan yang terendah terlihat pada budidaya umur 1 hari sebesar 0.18 $\mathrm{mgO}_{2} / \mathrm{L} / \mathrm{jam}$, sedangkan pada hari-hari lain bersifat stabil dan moderat dengan kisaran ratarata $0.68 \mathrm{mgO}_{2} / \mathrm{L} / \mathrm{jam}$. Tingkat transfer oksigen kincir yang berbeda-beda pada setiap harinya, dipengaruhi oleh keadaan ekosistem dan lingkungan tambak yang dinamis. Hal ini disebabkan, karena tingkat transfer oksigen kincir air secara aktual di lapang dipengaruhi oleh kondisi proses kimia fisika di kolam pada saat itu juga [15].

Selain itu, perbedaan tingkat transfer oksigen oleh kincir air dapat disebabkan oleh jenis spesifikasi kincir ketika menghasilkan kibasan pada bagian permukaan kolam untuk membuat percikan air [11]. Produksi transfer oksigen dari kincir yang berbeda bisa disebabkan juga dari bentuk ukuran kolam dan jam operasi kincir yang tidak konsisten [22]. Jadi dapat disebutkan bahwa fluktuasi tingkat transfer oksigen kincir air selain dipengaruhi oleh kondisi lingkungan, bisa juga disebabkan oleh faktor teknis atau non-teknis. Jenis kincir air yang beragam dan canggih akan menghasilkan nilai SAE (Standart Aeration Efficiency) dan SOTR (Standart Oxygen Transfer) yang optimum [21]. Sehingga, antara tenaga, kecepatan kibasan dan tingkat efisiensi transfer oksigen yang dihasilkan juga akan semakin optimal [36].

Tingkat transfer oksigen yang dinamis dari penggunaan kincir air sebagai alat perekayasa budidaya, selain berguna untuk kepentingan teknis budidaya, juga berguna sebagai cara alternatif penghematan biaya operasional selama budidaya. Yakni, dengan meminimalisir pemborosan biaya operasional akibat penggunaan jumlah dan kapasitas kincir air yang tidak tepat guna. Secara umum, pendekatan ekonomi digunakan sebagai metode rekayasa untuk menentukan jenis model kincir air yang paling efektif berdasarkan ukuran kolam serta jumlah padat tebar supaya lebih efektif dan mudah dalam melakukan perawatan ketika siklus budidaya berjalan $[9,43]$. 


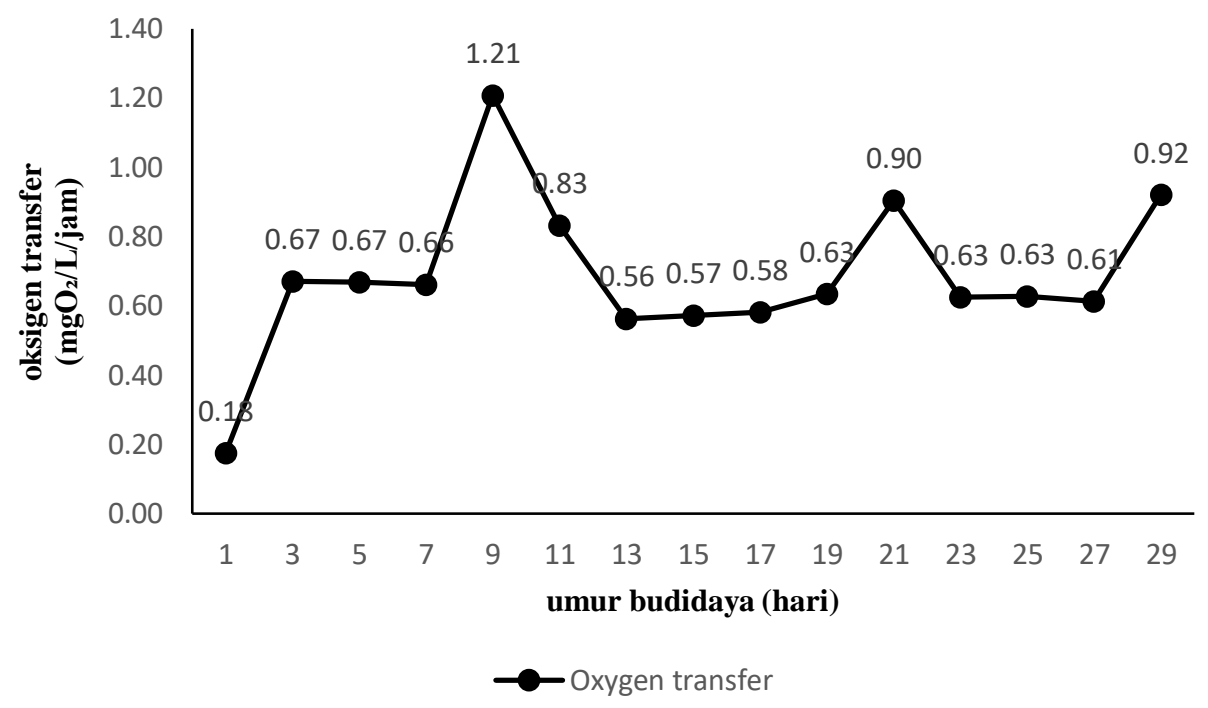

Gambar 2. Tingkat transfer oksigen oleh kincir air selama periode blind feeding.

\section{Nilai variabel kualitas air dan volume air tambak selama periode blind feeding}

Nilai variabel penelitian selama masa 30 hari awal budidaya secara rata-rata dapat dilihat pada Tabel 1. Rata-rata nilai transfer oksigen oleh aktifitas penggunaan kincir air dengan kapasitas penggunaan $2 \mathrm{HP}$ kincir air terhitung sebanyak $0.68 \mathrm{KgO}_{2} / \mathrm{L} / \mathrm{h}$ atau per 1 HP didapatkan nilai transfer oksigen sebesar $0.34 \mathrm{KgO}_{2} / \mathrm{L} / \mathrm{h}$. Nilai transfer oksigen tersebut lebih rendah dari nilai standart oksigen transfer kincir air hasil penelitian sebelumnya [32], sebesar $34.77 \mathrm{KgO}_{2} / \mathrm{h}$ dengan menggunakan kapasitas kincir air sebanyak 14 HP atau ratarata per $1 \mathrm{HP}$ didapatkan nilai standart oksigen transfer sebesar $2.48 \mathrm{KgO}_{2} / \mathrm{L} / \mathrm{h}$. Tetapi, nilai transfer oksigen kincir air pada penelitian ini terhitung hampir sama dengan hasil penelitian lain [3], yang menggunakan 4 HP kincir air didapatkan nilai oksigen transfer sebesar 2.95 $\mathrm{KgO}_{2} / \mathrm{L} / \mathrm{h}$, atau rata-rata per $1 \mathrm{HP}$ didapatkan estimasi transfer oksigen sebanyak 0.74 $\mathrm{KgO}_{2} / \mathrm{L} / \mathrm{h}$. Sementara untuk parameter kualitas air, yang pertama adalah konsentrasi oksigen terlarut yang terhitung rata-rata sebesar 6.35 $\mathrm{mg} / \mathrm{L}$. Konsentrasi oksigen terlarut pada penelitian ini terpantau cukup stabil dibandingkan dari beberapa penelitian yang sudah pernah dilakukan, yakni sebesar 7.99 $\mathrm{mg} / \mathrm{L} \quad$ dan $4.47 \quad \mathrm{mg} / \mathrm{L} \quad[10,18]$. Kadar konsentrasi oksigen terlarut di kolam selama masa budidaya sangat berdampak pada indikator produktifitas kolam [5].

Untuk suhu perairan tambak, selama penelitian terhitung rata-rata sebesar $29.8^{\circ} \mathrm{C}$, kondisi tersebut tercatat lebih tinggi dibandingkan hasil penelitian di tambak Banyuwangi, Jawa Timur sebesar $26.36^{\circ} \mathrm{C}$ [41]. Nilai suhu yang optimal pada sistem budidaya intensif udang vannamei (Litopenaeus vannamei) sangat berpengaruh terhadap performa pertumbuhan, tingkat kelangsungan hidup, nilai konversi pakan dan nilai parameter fisika-kimia air [31,49]. Sementara, untuk kadar $\mathrm{pH}$ perairan tambak secara rata-rata berada pada nilai 7.9. Nilai $\mathrm{pH}$ tersebut sama dengan hasil penelitian sebelumnya, yang mendapatkan nilai $\mathrm{pH}$ tertinggi pada angka 7.9 pada budidaya udang vannamei saat musim panas di Bangladesh [35]. Angka tersebut merupakan nilai $\mathrm{pH}$ yang optimum untuk pertumbuhan udang [16]. Salinitas selama masa penelitian terhitung ratarata sebesar 8 ppt. Nilai tersebut jauh lebih rendah dibandingkan rata-rata salinitas untuk budidaya dang vannamei pada perairan tropis sebesar 38 ppt [6]. Nilai salinitas yang terlalu rendah dapat mempengaruhi performa pertumbuhan dan tingkat kelangsungan hidup 
udang [13], sedangkan kadar salinitas yang terlalu tinggi akan berpengaruh terhadap tingkat retensi dan osmoregulasi nutrisi pada tubuh udang [23].

Sedangkan volume air tambak selama periode blind feeding rata-rata sebanyak 440 $\mathrm{m}^{3}$. Kapasitas volume air selama penelitian sangat stabil, hal ini dikarenakan kontruksi tambak yang sangat bagus, sehingga dapat meminimalisir terjadinya kebocoran kolam.

Tabel 1. Nilai rata-rata volume dan parameter kualitas air selama periode blind feeding

\begin{tabular}{|c|c|c|c|c|c|c|}
\hline & $\begin{array}{c}\text { OTR } \\
\left(\mathrm{KgO}_{2} / \mathrm{L} / \mathrm{h}\right)\end{array}$ & $\begin{array}{c}\text { DO } \\
(\mathrm{mg} / \mathrm{L})\end{array}$ & $\begin{array}{l}\text { Suhu } \\
\left({ }^{0} \mathrm{C}\right)\end{array}$ & pH & $\begin{array}{c}\text { Salinitas } \\
(00 / 0)\end{array}$ & $\begin{array}{c}\text { Vol. air } \\
\left(\mathrm{m}^{3}\right)\end{array}$ \\
\hline $\begin{array}{l}\text { Baku } \\
\text { mutu }\end{array}$ & $\begin{array}{c}2.95 \\
\text { (Bhuyar,2009) }\end{array}$ & $\begin{array}{c}>4 \\
(W W F, 2014)\end{array}$ & $\begin{array}{c}28-32^{0} \\
(W W F, 2014)\end{array}$ & $\begin{array}{c}7.5-8.0 \\
(W W F, 2014)\end{array}$ & $\begin{array}{c}15-25 \\
\text { (WWF,2014) }\end{array}$ & $\begin{array}{c}c>70 \% \\
\text { Total Volume } \\
\text { (WWF,2014) }\end{array}$ \\
\hline Rerata & $0.68 \pm 0.22$ & $6.35 \pm 0.36$ & $29.8 \pm 0.45$ & $7.9 \pm 0.141$ & $8 \pm 0.86$ & $4.4 \pm 0.00$ \\
\hline Terendah & 0.18 & 5.78 & 28.63 & 7.8 & 6 & 4.4 \\
\hline Tertinggi & 1.21 & 6.72 & 30.4 & 8.2 & 10 & 4.4 \\
\hline
\end{tabular}

Selain itu, banyak sedikitnya volume air tambak juga sangat dipengaruhi oleh proses penggunaan air pada proses water budget. Water budget sangat dipengaruhi oleh tingkat penggunaan air dari proses keluar-masuk air selama periode budidaya [38]. Proses keluar masuk air pada sistem budidaya itu sendiri dapat berasal dari proses presipitasi, limpasan, dan proses pergantian air, sedangkan air keluar dapat berasal dari proses evaporasi, rembesan, dan siphon [8,27]. Penentuan water budget sangat dipengaruhi oleh tingkat produktifitas perairan dan juga sebagai langkah untuk mitigasi kualitas air pada ekosistem budidaya $[8,26]$. Selain itu, kapasitas volume air tambak akibat adanya proses ganti air yang dinamis berdampak juga terhadap laju pertambahan berat udang yang dipelihara [12].

\section{Hubungan tingkat transfer oksigen dengan volume dan kualitas air tambak}

Tingkat transfer oksigen oleh aktifitas penggunaan kincir air secara langsung berhubungan dengan dinamika kualitas air tambak selama masa blind feeding. Hubungan antara nilai tingkat transfer oksigen dari aktifitas kincir air dengan kualitas air dapat dilihat pada Tabel 2.

Berdasarkan data hasil uji korelasi pada Tabel 2., menunjukan bahwa tingkat transfer oksigen oleh aktifitas penggunaan kincir air memiliki hubungan yang sangat kuat dengan nilai salinitas dan suhu air tambak, serta tidak memiliki hubungan terhadap parameterparameter lain seperti oksigen terlarut, $\mathrm{pH}$ dan volume air tambak. Nilai salinitas air akan berpengaruh terhadap nilai efisiensi aerasi oleh kincir air di tambak, selain itu, tingkat aerasi yang optimal akan sangat berpengaruh pada darajat stratifikasi suhu di tambak $[1,37]$. Nilai salinitas yang optimum untuk menghasilkan tingkat standart transfer oksigen yang paling maksimum adalah sebesar 30 ppt [46]. Sedangkan stratifikasi nilai suhu di kolam disebabkan oleh proses agitasi dan turbulensi akibat percikan kincir air yang dinamis [39].

Nilai salinitas pada penelitian ini memiliki hubungan keeratan yang sangat kuat dengan tingkat transfer oksigen kincir air. Salinitas adalah parameter penting yang mempengaruhi kemampuan transfer oksigen oleh kincir air pada berbagai level konsentrasi [11]. Peningkatan nilai salinitas secara teknis akan cenderung mengurangi tekanan permukaan air, tekanan yang kecil akan membuat kontak luas penampang permukaan kincir menjadi lebar, sehingga akan meningkatkan daya turbulensi serta laju difusi oksigen dari udara menuju air [44,45]. Selain itu, hubungan teknis antara peningkatan kadar salinitas tambak terhadap penggunaan kincir air, akan menyebabkan sebaran partikel gelembung serta diameter titik percikan air yang dihasilkan oleh kincir air menjadi lebih kecil, sehingga akan berpengaruh terhadap kenaikan kecepatan aliran rotasi roda kincir dalam berputar [3,32]. Kenaikan kecepatan rotasi vertikal kincir air, akan berdampak terhadap tingkat efisiensi transfer oksigen air (SOTR) yang lebih optimal di tambak [36]. 
Tabel 2. Hubungan tingkat transfer oksigen dengan volume dan parameter kualitas air tambak

\begin{tabular}{|c|c|c|c|c|c|c|c|}
\hline & & OTR & DO & suhu & pH & Salinitas & Volume air \\
\hline OTR & $\begin{array}{l}\text { Pearson } \\
\text { correlation }\end{array}$ & 1 & .492 & $.628^{*}$ & -.204 & $.980 * *$ & .000 \\
\hline & $\begin{array}{c}\text { Sig. } \\
\text { (2-tailed) }\end{array}$ & & .063 & .012 & .466 & .000 & .000 \\
\hline & $\mathrm{N}$ & 15 & 15 & 15 & 15 & 15 & 15 \\
\hline
\end{tabular}

Titik dan jumlah penggunaan kincir air di tambak, akan mempengaruhi sebaran suhu perairan [25]. Sebaran suhu yang dipengaruhi oleh mekanisme pengadukan di permukaan air, secara temporal akan berdampak pada tinggi rendahnya proses difusi dan kelarutan oksigen. Kelarutan oksigen di tambak, selain dipengaruhi oleh kondisi suhu dan salinitas air, juga dikarenakan oleh penggunaan type jenis kincir air yang sesuai $[2,8]$. Penggunaan dan peletakan jenis kincir yang sesuai akan menentukan efektifitas elevasi geometris kincir ketika beroperasi [21]. Hal lain yang dapat dijelaskan antara hubungan tingkat transfer oksigen dengan suhu. Bahwa distribusi vertikal transfer oksigen oleh kincir, dalam ekosistem kolam akan mempengaruhi tingkat perombakan bahan organik di sedimen, yang dimana tingkat efektifitasnya sangat dipengaruhi oleh stabilitas kondisi termal dan kadar oksigen yang mencukupi [33].

\section{KESIMPULAN}

Kesimpulan dari hasil penelitian ini, menunjukan bahwa selama periode blind feeding budidaya intensif udang vannamei (Litopenaeus vannamei), tingkat transfer oksigen dari aktifitas pemakaian kincir air bersifat fluktuatif. Serta efektifitas transfer oksigen dari kincir memiliki hubungan yang erat dipengaruhi ataupun mempengaruhi oleh kadar salinitas dan suhu air di tambak.

\section{DAFTAR PUSTAKA}

[1] Abdelrahman, H.A. and Boyd, C.E., 2018. Effects of mechanical aeration on evaporation rate and water temperature in aquaculture ponds. Aquaculture Research. 49: 2184-2192.

[2] Armstrong, M.S., and Boyd, C.E., 1982. Oxygen transfer calculations for a tractorpowered paddlewheel aerator. Transactions of the american fisheries society. 111: 361-366.

[3] Bhuyar, L.B., Thakre, S.B., and Ingole, N.W., 2009. Design characteristic of Curved Blade aerator w.r.t aeration efficiency and overall oxygen transfer coefficient and comparison with CFD modeling. International Journal of Engineering, Science and Technology. 1 (1): 1-15.

[4] Boyd, E.C., 1998. Pond water aeration systems. Aquaculture Engineering. 18: 940.

[5] Boyd, C.E., and Hanson, T., 2010. Dissolved-oxygen concentrations in pond aquaculture. Global Aquaculture Advocate: 40-41.

[6] Budiardi, T., Muluk. C., Widigdo. B., Praptokardiyo. K., dan Soedharma. D., 2008. Tingkat pemanfaatan pakan dan kelayakan kualitas air serta estimasi pertumbuhan dan produksi udang vaname (Litopenaeus vannamei. Boone 1931) pada sistem intensif. Jurnal Ilmu-ilmu Perairan dan Perikanan Indonesia. 15 (2): 109-116.

[7] Delgado, P.C., Avnimelech. Y., McNeil. R., Bratvold. D., Browdy. C.L., and Sandifer. P., 2003. Physical, chemical and 
biological characteristics of distinctive regions in paddlewheel aerated shrimp ponds. Aquaculture. 217.: 235-248.

[8] Edhy, W.A., Azhary. K., Pribadi. J., dan Chaerudin. M.K., 2010. Budidaya udang putih (Litopenaeus vannamei.Boone, 1931). CV. Mulia Indah. Jakarta: 193.

[9] Engle C.R., 1989. An economic comparison of aeration devices for aquaculture ponds. Aquacultural Engineering. 8: 193-207.

[10] Fakhri, M., Budianto. B., Yuniarni. A., and Hariati. A.M., 2015. Variation in Water Quality at different Intensive Whiteleg Shrimp, Litopenaeus vannamei, Farms in East Java, Indonesia. Nature Environment and Pollution Technology An International Quarterly Scientific Journal. 14 (1): 65-70.

[11] Fast, A.W., Tan. E.C., Stevens. D.F., Olson. J.C., Qin. J., and Barclay. D.K., 1999. Paddlewheel aerator oxygen transfer efficiencies at three salinities. Aquaculture Engineering. 19: 99-103.

[12] Gaber, M.M., Omar. E.A., Rahim. M.A., Nour. A.M., Zaki. M.A., and Srour. T.M., 2012. Effects of stocking density and water exchange rates on growth performance of tiger shrimp, Penaeus semisulcatus cultured in earthen ponds. $J$. Aquacult Res Dev. 3 (7): 1-5.

[13] Gao, W., Tian. L., Huang. T., Yao. M., Hu. W., Xu. Q., 2016. Effect of salinity on the growth performance, osmolarity and metabolism-related gene expression in white shrimp Litopenaeus vannamei. Aquaculture Reports. 4: 125-129.

[14] Gicos, A., 1993. Shrimp grow-out culture techniques in the Philippines. Proceeding of The Aquaculture Workshop for SEAFDEC; 8-11 September 1992: 173.

[15] Hopkins, J.S., Stokes. A.D., Browdy. C.L., and Sandifer. P.A., 1991. The relationship between feeding rate, paddlewheel aeration rate and expected dawn dissolved oxygen in intensive shrimp ponds.Aquaculture Engineering. 10: 281-290.

[16] Islam, M.S., Kamal. A.H.M.M., Wahab. M.A., and Dewan. S., 2004. Water quality parameters of coastal shrimp farms from southwest and southeast regions of Bangladesh. Bangladesh J.Fish. Res. 8 (1): 53-60.

[17] Jayraj, P., Roy. S.M., Mukherjee. C.K., Mal. B.C., 2018. Design characteristics of submersible aerator. Turkish Journal of Fisheries and Aquatic Sciences. 18: 10171023.

[18] Junda, M., 2018. Development of intensive shrimp farming, Litopenaeus vannamei in land-based ponds: production and management. $2^{\text {nd }}$ International Conference on Statistics, Mathematics, Teaching, and Research. 1028: 1-6.

[19] Kang, Y.H., Lee. M.O., Choi. S.D., and Sin. Y.S., 2004. 2-D Hydrodynamic model simulating paddlewheel-driven circulation in rectangular shrimp culture ponds. Aquaculture. 231: 163-179.

[20] Kitazawa, D., and Zhang. J., 2016. Measurement of water Current Field Created by Paddle Wheel Aerators in Shrimp Culture Pond. IEEE: 1-3.

[21] Kumar, A., Moulick. S., and Mal. B.C., 2010. Performance evaluation of propeller-aspirator-pump aerator. Aquaculture Engineering. 42: 70-74.

[22] Kumar, A., Moulick. S., and Mal. B.C., 2013. Selection of aerators for intensive aquacultural pond. Aquaculture Engineering. 56: 71-78.

[23] Maica, P.F., Borba. M.R., Martins. T.G., and Junior. W.W., 2014. Effect of salinity on performance and body composition of 
Pacific white shrimp juveniles reared in a super-intensive system. Revista Brasileira de Zootecnia. 43 (7): 343-350.

[24] Makmur, Fahrur. M., dan Undu. M.C., Pengaruh tipe kincir terhadap produksi tambak udang vaname (Litopenaeus vannamei) superintensif. 2016. Prosiding Forum Inovasi Teknologi Akuakultur: 277-284.

[25] Mohanty R.K., 2001. Effect of pond aeration on growth and survival of Penaeus monodon Fab. Bangladesh J. Fish. Res., 5(1): 59-65.

[26] Mohanty, R.K., Mishra. A., and Patil. D.U., 2014. Water budgeting in black tiger shrimp Penaeus monodon culture using different water and feed management systems. Turkish Journal of Fisheries and Aquatic Sciences. 14: 487496.

[27] Nath, S.S., and Bolte. J.P., 1998. A water budget model for pond aquaculture. Aquacultural Engineering. 18: 175-188.

[28] Nugraha, N.P.A., Agus. M dan Mardiana. T.Y., 2017. Rekayasa kincir air pada tambak ldpe udang vannamei (Litopenaeus vannamei) di tambak unikal Slamaran. PENA Akuatika. 16 (1): 103115.

[30] Nugroho, L.R., Sukardi., and Triyatmo. B., 2016. Penerapan cara budidaya ikan pada pembesaran udaang vanname (litopenaeus vannamei) di pesisir Daerah Istimewa Yogyakarta. Jurnal Perikanan Universitas Gadjah Mada. 18 (2): 47-53.

[31] Palafox, J.T.P., Pavia. A.A., Lopez. D.G.M., Figueroa. J.L.A., Reynoso. F.L., Chavez. M.D.R.C., Leal. H.E., Luna. A.R., Ozuna. F.P., Vargasmachuca. S.G.C., and Gomez. V.P., 2019. Response surface analysis of temperature-salinity interaction effects on water quality, growth and survival of shrimp Penaeus vannamei postlarvae raised in biofloc intensive nursery production. Aquaculture. 503: 312-321.

[32] Peterson, E.L., and Walker. M.B., 2002. Effect of speed on Taiwanese paddlewheel aeration. Aquaculture Engineering. 26: 129-147.

[33] Phan-Van M., Rousseau D., and De Pauw N., 2008. Effects of fish bioturbation on the vertical distribution of water temperature and dissolved oxygen in a fish culture-integrated waste stabilization pond system in Vietnam. Aquaculture. 281: 28-33.

[34] Pushparajan, N., and Soundarapandian. P., 2010. Recent farming of marine black tiger shrimp, Penaeus monodon (Fabricius) in South India. African Journal of Basic \& Applied Sciences. 2(12): 33-36.

[35] Rahman, M.Z., Zaman. M.F.U., Khondoker. S., Jaman. M.H.U., Hossain. M.L., and Bappa. S.B., 2015. Water quality assessment of a shrimp farm: A study in a salinity prone area of Bangladesh. International Journal of Fisheries and Aquatic Studies. 2 (5): 9-19.

[36] Roy, S.M., Moulick. S., Mukherjee. C.K., and Mal. B.C., 2015. Effect of Rotational Speeds of Paddle Wheel Aerator on Aeration Cost. American Research Thoughts. 2 (1): 3069-3087.

[37] Ruttanagosrigit, W., Musig. Y., Boyd. C.E., and Sukcharoen. L., 1991. Effect of salinity on oxygen transfer by propelleraspirator-pump and paddle wheel aerators used in shrimp farming. Aquacultural Engineering. 10: 121-131.

[38] Sharma, K.K., Mohapatra. B.C., Das. P.C., Sakar. B., and Chand. S., 2013. Water budgets for freshwater aquaculture ponds with reference to effluent volume. Agricultural Sciences. 4 (8): 253-259. 
[39] Sipauba-Tavares L.H., Freitas A.M., and Braga F.M.S., 1999. The use of mechanical aeration and its effects on water mass. Rev. Brasil. Biol., 59(1): 3342.

[40] Supono., 2015. Manajemen lingkungan untuk akuakultur. Plantaxia. Yogyakarta: 116.

[41] Supriatna., Marsoedi., Hariati. A.M., and Mahmudi. M., 2017. Dissolved oxygen models in intensive culture of whiteleg shrimp, Litopenaeus vannamei, in East Java, Indonesia. AACL Bioflux. 10(4): 768-778.

[42] Suwoyo, H.S., 2008. Tingkat konsumsi oksigen sedimen pada dasar tambak intensif udang vaname (Litopenaeus vannamei). [Tesis]. Institut Pertanian Bogor: 115.

[43] Tanveer M., Roy S.M., Vikneswaran M., Renganathan P., and Balasubramanian S., 2018. Surface aeration systems for application in aquaculture: a review. International Journal of Fisheries and Aquatic Studies. 6(5): 342-347.

[44] Tucker C.S., and Hargreaves J.A., 2004. Pond water quality. Developments in Aquaculture and Fisheries Science. 34: 215-278.

[45] Tucker, C., 2005. Pond aeration. SRAC Publication. No. 3700: 1-2.

[46] Vinatea, L., and Carvalho. J.W., 2007. Influence of water salinity on the SOTR of paddlewheel and propeller-aspiratorpump aerators, its relation to the number of aerators per hectare and electricity cost. Aquacultural Engineering. 37: 73-78.

[47] Wijayanto, D., Nursanto. D.B., Kurohman. F., Nugroho. R.A., 2017. Profit maximization of whiteleg shrimp (Litopenaeus vannamei) intensive culture in Situbondo Regency, Indonesia. AACL Bioflux. 10(6): 1436-1444.
[48] World Wildlife Fund., 2014. Better Management Practice budidaya udang vannamei tambak semi intensif dengan Instalasi Pengelolaan Air Limbah (IPAL). WWF Indonesia. Jakarta: 1-37.

[49] Wyban, J., Walsh. W.A., and Godin. D.M., 1995. Temperature effect on growth, feeding rate and feed coversion of the Pacific white shrimp (Penaeus vannamei). Aquaculture. 138: 267-279. 